\title{
Effect of Rice Residue and Weed Management Practices on Growth and Yield of Wheat
}

\author{
B. L. Meena ${ }^{1}$, R. K. Singh ${ }^{2}$, Raghuvir Singh Meena ${ }^{3}$, \\ Narendra Kumawat ${ }^{4 *}$ and Neeshu Joshi ${ }^{5}$
}

\author{
${ }^{1}$ College of Agriculture, Lalsot (SKNAU, Jobner), Dausa, Rajasthan, India \\ ${ }^{2}$ Department of Agronomy, Institute of Agricultural Sciences, \\ Banaras Hindu University, Varanasi-221005, Uttar Pradesh, India \\ ${ }^{3}$ Agricultural Research Station, Sriganganagar, Rajasthan, India \\ ${ }^{4}$ AICRP on Dryland Agriculture, College of Agriculture, \\ Indore-452 001, Madhya Pradesh, India \\ ${ }^{5}$ Agricultural Research Sub-station, Sumerpur - 306 902, Pali, Rajasthan, India
}

\section{*Corresponding author}

\section{A B S T R A C T}

\section{Keywords}

Herbicide,

Metsulfuron, Rice

residue,

Sulfosulfuron,

Wheat yield

Article Info

Accepted:

18 May 2020

Available Online:

10 June 2020
A Field experiments were carried out from 2009-10 and 2010-11 to evaluate the efficiency of herbicides under different rice residue management practices in wheat. The herbicide treatments included application of sulfosulfuron alone and tank mix Sulfosulfuron $25 \mathrm{~g} / \mathrm{ha}+$ metsulfuron $4 \mathrm{~g} / \mathrm{ha}$ and isoproturon $1.0 \mathrm{~kg} / \mathrm{ha}+$ metsulfuron 4 $\mathrm{g} / \mathrm{ha}$. Residue mulching reduced weed density, resulting in improvement of growth and yield attributing characters of wheat followed by residue incorporated and residue retained treatments. Among the different herbicide application, Sulfosulfuron $25 \mathrm{~g} / \mathrm{ha}$ + metsulfuron $4 \mathrm{~g} / \mathrm{ha}$ was recorded higher, growth, yield attributes and wheat yield; and harvest index followed by isoproturon $1.0 \mathrm{~kg} / \mathrm{ha}+$ metsulfuron $4 \mathrm{~g} / \mathrm{ha}$ and sulfosulfuron $25 \mathrm{~g} / \mathrm{ha}$. It was concluded that rice residue mulching management was best among the given residue management practices and tank mix application of Sulfosulfuron $25 \mathrm{~g} / \mathrm{ha}+$ metsulfuron $4 \mathrm{~g} / \mathrm{ha}$ was best among other treatments in terms of increased wheat yield.

\section{Introduction}

Wheat (Triticum aestivum L.) stands second in grain production in the world and most widely cultivated food crop (Maurya et al., 2014). In India, it is second important staple food crop cultivated over an area of 30.54 million hectares with a total production of
94.57 million tones and total productivity of $3370 \mathrm{~kg}$ per hectare. Uttar Pradesh has largest share in area with 9.75 million hectare $(32 \%)$, followed by Madhya Pradesh (18.75\%), Punjab (11.48\%), Rajasthan (9.74\%), Haryana (8.36\%) and Bihar (6.82\%). However, a major expansion in wheat area was observed in the states such as Jharkhand 
(51\%), Madhya Pradesh (27\%) and Rajasthan $(13 \%)$ to all India production of wheat (Ramadas et al., 2019). Rice-wheat cropping system is the predominant cropping system in India. About 400 million tons of crop residues are produced in India alone. In areas where mechanical harvesting is practiced, a large quantity of crop residues are left in the field which necessitates proper management and utilization of crop residue which can be reused as a source of nutrient supply. Further the burning of crop residue which is a cost effective method of disposal of residue but it causes harmful effect on the environment which calls for exploring the residue as a means of compost or mulch and eco-friendly options to manage the residues. Crop residues left on the surface can suppress weed seed germination and or seedling growth and complement the effects of herbicide (Crutchfield et al., 1986). Brar et al., (1998) however, observed that there was no significant effect of burning or incorporation of crop residue on the efficiency of butachlor applied to rice and isoproturon applied to wheat in rice-wheat cropping systems (Kumar et al., 2017 and Kumawat et al., 2018).

Weed infestation is also a serious factor in rice-wheat cropping system. Besides the crop rotation (Anderson and Beck, 2007), tillage also influences the type of weed flora. Among grassy weeds, Phalaris minor (L.) Retz. and among broad leaved weeds Rumex detasus (L.) are of major concern in irrigated wheat under rice-wheat cropping system in India (Balyan and Malik, 2000). Under such situation, combination of grassy and nongrassy herbicides effectively controls the weeds and improve crop yield. Tank mix application of both grassy and broad leaf herbicides such as isoproturon + metsulfuron, sulfosulfuron + metsulfuron and many others have been reported promising to control complex weed flora and resulted in significant increase in wheat yield when compared with alone application of component herbicides (Meena and Singh, 2011 and Paswan et al., 2017). In addition to influencing the weed growth and population, crop residues management and tillage practices also influence the efficiency of herbicides (Kumar and Goh, 2004 and Yadav et al., 2018). Keeping in the view the above facts, an investigation was planned to study on the response of herbicides under different rice residue management practices in wheat.

\section{Materials and Methods}

A field experiments were conducted during winter (rabi) of 2009-10 and 2010-11 at the Agricultural Research Farm, Institute of Agricultural Sciences Banaras Hindu University, Varanasi. The eastern indogangetic soil was sandy clay loam in texture having pH.7.8 and moderately fertile, organic carbon $0.43 \%$ and available $\mathrm{N}, \mathrm{P}_{2} \mathrm{O}_{5}$ and $\mathrm{K}_{2} \mathrm{O}$ was 205.14, 17.46 and $237.34 \mathrm{~kg} / \mathrm{ha}$, respectively. The treatment comprised of three rice residue management practices (retained, mulching and incorporation) in main plots and five weed control treatments, viz., weedy, weed free, sulfosulfuron $25 \mathrm{~g} / \mathrm{ha}$ alone, tank mix Sulfosulfuron $25 \mathrm{~g} / \mathrm{ha}+$ metsulfuron $4 \mathrm{~g} / \mathrm{ha}$ and isoproturon $1.0 \mathrm{~kg} / \mathrm{ha}$ + metsulfuron $4 \mathrm{~g} / \mathrm{ha}$ in sub plots. The experiment was laid-out in spilt plot design with four replications. After harvesting of rice, anchored residue to the height of $30 \mathrm{~cm}$ were retained and incorporated before sowing of wheat crop. Whereas, the harvested rice residue at the rate of 4.0 tonnes were uniformly spread between crop rows after germination of crop. Wheat cultivar HUW 234 was sown with the help of zero-till seed cum ferti-drill on December during 2009-10 and 2010-11. A uniform fertilizer dose of 120-60-60 Kg N-P-K/ha was applied in the form of urea, single super phosphate and muriate of potash in all the plots. One third nitrogen and full dose of phosphorus and 
potassium was applied as basal and remaining two thirds was applied in two equal splits at crown root initiation and panicle iniation stages. Existing weed species were destroyed by application of glyphosate at $2 \mathrm{~kg} / \mathrm{ha}$ (3 days before sowing). In weed free treatment weeds were manually removed with the help of hand hoe (khurpi) when appears in crop till the harvest of the crops. Herbicides were applied as post emergence at 32 DAS with the help of hand operated knapsack sprayer, fitted with flat fan nozzle with water as carrier at 600 liters/ha.

The heights of ten randomly tagged plants were measured at different successive stages of crop growth with the help of meter scale from base of the plant to the tip of uppermost leaf of the plant before ear emergence and up to the tip of ear head after heading, averaged and expressed in $\mathrm{cm}$ starting from 30, 60, 90 DAS and at harvest. The number of tillers were recorded randomly from three places per running meter in each plot at 30, 60, 90 days after sowing and at harvest stage and average value was expressed in terms of tillers per meter row length.

Plant samples of half-running meter were taken randomly from sample row in each plot at 30, 60, 90 days after sowing and at harvest stage of crop. Samples were dried in oven at $70 \pm 1{ }^{0} \mathrm{C}$ till the constant weight obtained, the weight of dry sample was expressed in terms of gm per row length. Ear heads were counted randomly at two places in net plot from an area of one meter square in each plot and expressed as average number of ear heads per meter square. Twenty ear-head were randomly selected from tagged plants in each plot and their length $(\mathrm{cm})$ was measured from neck node to tip of the top most spikes and average length was calculated. The grains of twenty selected ear-heads were counted and averaged to get the number of grains/ear heads.
One thousand grains were counted from representative sample of each treatment drawn from winnowed and cleaned produce, and their weight expressed in gram.

After threshing of net plot area of each treatment, the grain was separated from the straw and cleaned. The grain yield was recorded plot wise, adjusted at $14 \%$ moisture level and there after expressed in $\mathrm{kg} / \mathrm{ha}$. After threshing of net plot area of each treatment, straw yield was recorded plot wise by subtracting grain yield from bundle weight and thereafter expressed in $\mathrm{kg} / \mathrm{ha}$.

All above ground plant parts harvested from net plot area were carefully bundled, tagged and taken to the threshing floor separately. The individual bundle was weighed after complete drying in the sun and the biological yield per plot was then converted into $\mathrm{kg} / \mathrm{ha}$. The harvest index was computed in term of grain yield expressed as percentage of biological yield (grain + straw) based on the per hectare yields.

Harvest index $(\mathrm{HI})=\frac{\text { Grain y ield }}{\text { Biological yield }} \times 100$

\section{Results and Discussion}

\section{Growth attributes}

Crop growth attributes data revealed that the plant height and dry matter accumulation were highest in plots having rice residue mulch which was at par with rice residue incorporated and significantly superior to rice residue retained in both years (Table 1). The superiority of rice residue mulch in respect of crop growth parameters can be discussed in light of the fact that this treatment caused maximum reduction in weeds growth resulting in more availability of light, moisture and nutrients than treatments. 
It is also evident that all the competitive features in crop against weeds were more prominent in rice residue mulch but least prominent in rice residue retained (Kumar et $a l .$, 2017). Among the different weed control treatments, weed free recorded the higher plant height and dry matter in comparisons to other herbicidal treatment in both the years.

Combination of sulfosulfuron $25 \mathrm{~g} / \mathrm{ha}+$ metsulfuron methyl $4 \mathrm{~g} / \mathrm{ha}$ had recorded more plant dry matter which was at par with isoproturon $1.0 \mathrm{~kg} / \mathrm{ha}+$ metsulfuron methyl 4 $\mathrm{g} / \mathrm{ha}$ and significantly superior to sulfosulfuron $25 \mathrm{~g} / \mathrm{ha}$ which had the lowest dry matter amongst herbicidal treatments.

The reason for higher values of growth parameters can be discussed in light of fact that crop under this treatment had comparatively less weed competition for resources which led to more crop growth than other treatments (Kumar et al., 2013 and Kumar et al., 2017).

\section{Yield and yield attributes}

Rice residue mulches showed better performance in improving yield attributes viz., number of ear head $/ \mathrm{m}^{2}$ and test weight that was significantly different from rice residue incorporated and rice residue retained.

Grain and biological yield were also found to be highest with rice residue mulch application and significantly different from rice residue retained which was at par with rice residue incorporated.

The better performance of yield and yield attributing characters was also reflected in the performance of harvest index, where Rice residue mulches recorded the highest harvest index and it was significantly superior than rice residue retained and statistically similar to rice residue incorporated in both the years.
The development of growth attributes is a function of dry matter accumulation by crop and its translocation is important for the formation of yield attributing characters of crop. Similar results were observed by Walia (2002) and Singh et al., (2006)

All the weed control treatments significantly outperformed the weedy in respect of yield attributes viz., ear head $/ \mathrm{m}^{2}$ and test weight and yield. An increase of $61 \%$ and $57 \%$ in grain yield in first year and $45 \% 43$ in biological yield in second year with weed free over the weedy was observed mainly owing to manual removal of associated weed flora and keeping the plots weed free in first and second years, respectively.

Combination of sulfosulfuron $25 \mathrm{~g} / \mathrm{ha}+$ metsulfuron methyl $4 \mathrm{~g} / \mathrm{ha}$ showed better performance in improving yield attributes in comparison to sulfosulfuron $25 \mathrm{~g} / \mathrm{ha}$ and it was at par with isoproturon $1.0 \mathrm{~kg} / \mathrm{ha}+$ metsulfuron methyl $4 \mathrm{~g} / \mathrm{ha}$ with respect to yield attributing characters viz., number of ear head $/ \mathrm{m}^{2}$, ear head length, number of grains/ear head, test weight.

Similarly the maximum harvest index was also recorded with the application of sulfosulfuron $25 \mathrm{~g} / \mathrm{ha}+$ metsulfuron methyl 4 g/ha. Chhokar and Malik (2002) reported that metsulfuron methyl controls mostly broad leaved weed species, whereas sulfosulfuron controls grasses and some broad leaved species. In the present investigation, application of sulfosulfuron and metsulfuron methyl provided broad spectrum weed control.

Therefore, after weeding, minimum weed density and dry weight and maximum grain yield was observed in this treatment. Similar findings have been also reported by Chhokar et al., (2007), Meena and Singh (2011) and Singh et al., (2012). 
Table.1 Effect of rice residue management and herbicides on growth attributes at 60 DAS, yield attributes and yield of wheat

\begin{tabular}{|c|c|c|c|c|c|c|c|c|c|c|c|c|c|c|}
\hline \multirow[t]{2}{*}{ Treatments } & \multicolumn{2}{|c|}{$\begin{array}{c}\text { Plant } \\
\text { height } \\
\text { (cm) }\end{array}$} & \multicolumn{2}{|c|}{$\begin{array}{l}\text { Dry matter } \\
\text { accumulation } \\
\text { (g/plant) }\end{array}$} & \multicolumn{2}{|c|}{ Ear heads/m $\mathbf{m}^{2}$} & \multicolumn{2}{|c|}{$\begin{array}{c}\text { Test } \\
\text { weight } \\
\text { (g) }\end{array}$} & \multicolumn{2}{|c|}{$\begin{array}{l}\text { Grain } \\
\text { yield } \\
\text { (kg/ha) }\end{array}$} & \multicolumn{2}{|c|}{$\begin{array}{c}\text { Biological } \\
\text { yield } \\
(\mathbf{k g} / \mathbf{h a})\end{array}$} & \multicolumn{2}{|c|}{$\begin{array}{c}\text { Harvest } \\
\text { index } \\
(\%)\end{array}$} \\
\hline & $\begin{array}{c}2009- \\
10\end{array}$ & $\begin{array}{c}2010- \\
11\end{array}$ & $\begin{array}{c}2009- \\
10\end{array}$ & $\begin{array}{c}2010- \\
11\end{array}$ & $\begin{array}{c}2009- \\
10\end{array}$ & $\begin{array}{c}2010- \\
11\end{array}$ & $\begin{array}{c}2009- \\
10\end{array}$ & $\begin{array}{c}2010- \\
11\end{array}$ & $\begin{array}{c}2009- \\
10\end{array}$ & $\begin{array}{c}2010- \\
11\end{array}$ & $2009-$ & $\begin{array}{c}2010- \\
11\end{array}$ & $\begin{array}{c}2009- \\
10\end{array}$ & $\begin{array}{c}2010- \\
11\end{array}$ \\
\hline \multicolumn{15}{|c|}{ Residue management } \\
\hline $\begin{array}{l}\text { Rice residue } \\
\text { retained }\end{array}$ & 69.99 & 71.06 & 361.01 & 362.01 & 318.25 & 320.30 & 40.21 & 41.11 & 3630 & 3835 & 9243 & 9650 & 39.19 & 39.67 \\
\hline $\begin{array}{l}\text { Rice residue } \\
\text { mulches }\end{array}$ & 73.76 & 74.80 & 364.48 & 365.51 & 325.55 & 327.65 & 42.06 & 43.31 & 4341 & 4574 & 10725 & 11163 & 40.16 & 40.68 \\
\hline $\begin{array}{l}\text { Rice residue } \\
\text { incorporated }\end{array}$ & 73.03 & 74.07 & 362.99 & 364.10 & 324.00 & 326.20 & 41.24 & 42.22 & 3919 & 4107 & 9857 & 10250 & 39.68 & 40.00 \\
\hline SEm \pm & 0.43 & 0.43 & 0.527 & 0.52 & 1.10 & 1.06 & 0.29 & 0.31 & 70 & 74 & 119 & 123 & 0.51 & 0.50 \\
\hline $\mathrm{CD}(\mathrm{P}=0.05)$ & 1.50 & 1.49 & 1.823 & 1.81 & 3.78 & 3.66 & 0.99 & 1.08 & 243 & 255 & 413 & 424 & NS & NS \\
\hline \multicolumn{15}{|c|}{ Weed management } \\
\hline Weedy check & 71.07 & 72.13 & 359.38 & 360.51 & 315.83 & 317.92 & 40.04 & 40.91 & 2835 & 3043 & 7669 & 8082 & 37.07 & 37.74 \\
\hline Weed free & 74.03 & 75.09 & 366.10 & 367.07 & 327.25 & 329.17 & 42.09 & 43.43 & 4563 & 4775 & 11130 & 11547 & 40.9 & 41.27 \\
\hline Sulfosulfuron & 71.43 & 72.44 & 361.01 & 362.08 & 319.67 & 322.08 & 40.72 & 41.74 & 3922 & 4126 & 9823 & 10231 & 39.93 & 40.33 \\
\hline $\begin{array}{l}\text { Sulfosulfuron + } \\
\text { metsulfuron }\end{array}$ & 72.82 & 73.89 & 364.47 & 365.52 & 326.17 & 328.25 & 41.66 & 42.66 & 4307 & 4515 & 10651 & 11063 & 40.38 & 40.74 \\
\hline $\begin{array}{l}\text { Isoproturon + } \\
\text { metsulfuron }\end{array}$ & 71.94 & 72.99 & 363.18 & 364.19 & 324.08 & 326.17 & 41.33 & 42.34 & 4191 & 4399 & 10435 & 10848 & 40.11 & 40.51 \\
\hline SEm \pm & 0.38 & 0.38 & 0.502 & 0.51 & 0.77 & 0.78 & 0.21 & 0.23 & 50 & 50 & 69 & 69 & 0.46 & 0.43 \\
\hline $\mathrm{CD}(\mathrm{P}=0.05)$ & 1.08 & 1.10 & 1.441 & 1.45 & 2.21 & 2.22 & 0.61 & 0.66 & 145 & 144 & 199 & 197 & 1.31 & 1.24 \\
\hline
\end{tabular}


Use of Rice residue mulches and control of weeds through application of Sulfosulfuron $25 \mathrm{~g} / \mathrm{ha}+$ metsulfuron methyl $4 \mathrm{~g} / \mathrm{ha}$ was found to result in better performance of wheat in terms of improvement in yield attributing character and increase in yield. It might be due to the result of better weed control facilitating the competitive ability of plants in using the resources efficiently.

\section{References}

Anderson R. L. and Beck D. L. 2007. Characterizing in central Dakota. Weed tech., 21: 76-79.

Balyan R. S. and Malik R. K. 2000. New herbicides for jagali palak (Rumex retroflexux L.). Indian J. Weed Sci., 32: 86-88.

Brar S. S., Kumar S., Brar L. S. and Walia S. S. 1998. Effect of crop residue management systems on the grain yield and efficacy of herbicides in rice-wheat sequence. Indian J. Weed Sci., 30: 3943.

Chhokar R. S. and Malik R. K. 2002. Isoproturon resistant Phalaris minor and its response to alternate herbicides. Weed Techno. 16: 116-123.

Chhokar R. S., Sharma R. K., Jat G. R., Pundir A. K. and Gathala M.K. 2007. Effect of tillage and herbicides on weeds and productivity of wheat under rice-wheat growing system. Crop Protec. 26 (11): 1689-1696.

Crutchfield D. A. 1986. The effect of wheat straw mulch on weed control and corn growth. Diss. Abstr. Int. B45, 2741 B.

Kumar K. and Goh K. M. 2004. Crop residues and management practices: Effect on soil quality, soil nitrogen dynamics crop yields and nitrogen recovery. $A d v$. Agron, 68: 197-329.

Kumar R., Kumawat N., Kumar S., Kumar R., Kumar M., Sah R. P. and Kumar A. 2017. Direct seeded rice: research strategies and opportunities for water and weed management. Oryza, 53 (4): 354-365.

Kumar R., Singh U. P. and Mahajan G. 2017. Influence of residue and weed management practices on no-till wheat (Triticum aestivum L.) under rice-wheat cropping system. Indian J. Soil Conserv., 45 (2): 198-202.

Kumar V., Singh S., Chhokar R. S., Malik R. K., Brainard D. C. and Ladha J. K. 2013. Weed management strategies to reduce herbicide use in zero-till ricewheat cropping systems of the IndoGangetic Plains. Weed Tech., 27: 241254.

Kumawat N., Kumar R., Singh M., Tomar I. S. Morya J., Yadav R. K. Sahu, Y. K. and Singh A. K. 2018. A study on chemical weed management in boro rice: A Review. Agric. Reviews, 39(1): 69-75.

Maurya P., Kumar V., Maurya K. K., Kumawat N., Kumar R. and Yadav M. P. 2014. Effect of potassium application on growth, yield and economics of wheat varieties. The Bioscane, 9 (4): 1371-1373.

Meena R. S. and Singh M. K. 2011. Weed management in late-sown zero-till wheat (Triticum aestivum) with varying seed rate. Indian J. Agron., 56 (2): 127132.

Paswan A. K., Mandal D., Kumawat N., Kumar J., Kumar R., Singh A. K. and Kumar A. 2017. Efficacy of separate and premix formulation of metsulfuronmethyl and carfentrazone-ethyl on weeds in wheat: A Review. J. Curr. Microbio. Appl. Sci., 6(7): 2439-2453.

Ramadas S., Kumar T. M. K. and Singh G. P. 2019. Wheat Production in India: Trends and Prospects. DOI: http://dx.doi.org/10.5772/intechopen.86 341

Singh A., Kaur R., Kang J. S. and Singh G. 
2012. Weed dynamic in rice-wheat cropping system. Global J. Bio. Agric. Health Sci., 1 (1): 7-16.

Singh R. and Yadav D. S. 2006. Effect of rice (Oryza sativa) residue and nitrogen on performance of wheat (Triticum aestivum) under rice wheat cropping system. Indian J. Agron., 55(2): 83-88.

Walia S. S., Brar S. S. and Klar D. S.1995. Effect of management of crop residue on soil properties in rice-wheat cropping systems. Environ. Sci., 13: 5. Yadav R. K., Kumawat N., Singh A., Tomar I. S., Singh M. and Morya J. 2018. Bioefficacy of new herbicides in mixture and alone on weed dynamic, yields and nutrient uptake of maize (Zea mays L.) under rainfed conditions. Indian $J$. Agric. Sci., 88 (7): 1123-1128.

\section{How to cite this article:}

Meena. B. L., R. K. Singh, Raghuvir Singh Meena, Narendra Kumawat and Neeshu Joshi. 2020. Effect of Rice Residue and Weed Management Practices on Growth and Yield of Wheat. Int.J.Curr.Microbiol.App.Sci. 9(06): 2361-2367. doi: https://doi.org/10.20546/ijcmas.2020.906.289 